Mehmet Akif Ersoy Üniversitesi Fen Bilimleri Enstitüsü Dergisi 10(1): 1-10 (2019)

The Journal of Graduate School of Natural and Applied Sciences of Mehmet Akif Ersoy University 10(1): 1-10 (2019)

Araştırma Makalesi / Research Paper

\title{
Okul Binalarında Bulunması Gereken Perde Duvar Oranı Üzerine Bir Çalışma
}

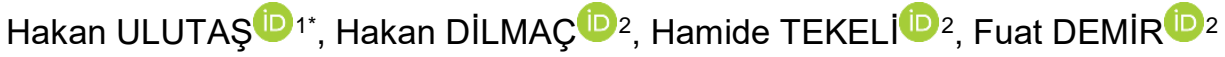 \\ ${ }^{1}$ Burdur Mehmet Akif Ersoy Üniversitesi, Mühendislik Mimarlık Fakültesi, Burdur \\ ${ }^{2}$ Süleyman Demirel Üniversitesi, Mühendislik Fakültesi, Isparta \\ Geliş Tarihi (Received): 22.12.2018, Kabul Tarihi (Accepted): 15.02.2019 \\ $\square$ Sorumlu Yazar (Corresponding author $\left.{ }^{\star}\right)$ : hakanulutas@gmail.com \\ (C) $+902482132746 \quad$ 皿 +902482132704
}

$\overline{O ̈ Z}$

Bu çalışma kapsamında, okul türü binaların depreme karşı güvenli olabilmesi için planda bulunması gereken perde duvar oranı kat adetine bağlı olarak belirlenmiştir. Bu amaçla 4, 6 ve 8 derslikli üç tip model bina kalıp planı seçilmiş ve her birinin her iki yönüne simetrik 4 adet perde duvar yerleştirilerek perdeli çerçeveli sistemler oluşturulmuştur. Seçilen 3 tip kalıp planının her biri 2, 3, 4 ve 5 katlı olarak modellenmiştir. Model binaların her biri 2 tip malzeme grubu için oluşturulmuştur. Böylece hesaplamalarda toplamda 24 adet tip okul binası dikkate alınmıştır. Üretilen bu model okul binalarının doğrusal elastik olmayan hesap yöntemiyle performans değerlendirilmesi yapılmıştır. Seçilen 24 adet model binanın her biri aşılma olasılığına göre hedeflenen minimum hedef performans seviyelerini sağlayana kadar perde duvarlar hesap yapılan doğrultuda 5'er cm artırılarak öngörülen performans seviyesini sağlayan en küçük perde duvar boyutları her iki doğrultu için elde edilmiştir. Belirlenen bu perde duvar boyutları kat alanlarına bölünerek kat adetine bağlı olarak perde duvar oranları belirlenmiştir.

Anahtar Kelimeler: Perde duvar oranı, Okul Binaları, Doğrusal Elastik Olmayan Yöntem, Deprem Güvenliği

\section{A Study on the Shear Wall Ratio in School Buildings}

\begin{abstract}
Within this current study, in order to be safe of school buildings against an earthquake, shear wall ratio, must have been a plan, was determined depending on floor type. In order to determine these approach, three types of model building formwork plans with 4, 6 and 8 classrooms were selected. Shear wall- frame systems have been created by placing 4 reinforced concrete shear walls symmetrically on both sides of each of the 3 selected formwork plans. Each of the 3 types of selected formwork plans were modeled as 2, 3, 4 and 5 stories. Each of the model buildings was built for 2 types of material combination. Thereby, a total of 24 types of school buildings were taken into account in the calculations. Performance evaluation of the 24 model school buildings produced was made by using nonlinear analysis method. The smallest reinforced concrete shear wall dimensions, provided the predicted performance level, are obtained by increasing by $5 \mathrm{~cm}$ the reinforced concrete shear walls in both directions. This process was carried out until each of the selected 24 model buildings provided the minimum target performance levels based on the probability of exceeding occurrence. Shear wall dimensions were determined by dividing specified curtain wall dimensions into floor areas. These shear wall ratios depend on floor type.
\end{abstract}

Keywords: Shear Wall Ratio, School Buildings, Nonlinear Analysis Methods, Seismic Safety

Hakan ULUTAŞ, https://orcid.org/0000-0003-1721-7268 Hakan DíLMAÇ, https://orcid.org/0000-0003-0346-8875

Hamide TEKELI, https://orcid.org/0000-0002-3515-6836

Fuat DEMiR, https://orcid.org/0000-0001-6726-3831 


\section{Giriş}

Ülkemizde meydana gelen depremlerde hasar görmüş veya göçmüş yapılar incelendiğinde bu yapıların bazılarının yatay deplasman talebini karşılayamadığı görülmektedir (Engin, 2017). Betonarme yapıların yatay ötelenme rijitliğini artırmak, katlar arasında yatay ötelenmeleri sınırlamak ve tersinir deprem yükleri altında yapıya süneklik sağlamak, yapıda perde duvar elemanlar kullanmakla mümkündür (Atımtay, 2001).

Deprem Bölgelerinde Yapılacak Binalar Hakkında Yönetmelik (DBYBHY, 2007)'de yapılarda bulunması gereken perde duvar miktarı ile ilgili bir oran bulunmamakla birlikte yapıda oluşabilecek maksimum göreli kat ötelenmeleri ile ilgili sınır değerler mevcuttur. Yatay yükler etkisinde kalan yapılardaki kat yer değiştirmelerini sınırlandırmak dolayısı ile göreli kat ötelemeleri ve ikinci mertebe momentlerini azaltmak için perde duvarların kullanılması oldukça etkili olmaktadır (Erken, 2012; Şahin vd., 2013).

Literatürde yapılarda \%1 oranında perde duvar bulunması gerektiği konusunda yaygın bir görüş mevcut olmakla birlikte farklı perde duvar oranları da mevcuttur. Atımtay (2001), 1-20 arası kat adetine sahip yapılarda bulunması gereken perde duvar oranını kat adetine bağlı olarak belirlenmiş olup bu oranı 1 katlı yapıda $\% 0.13,20$ katlı yapıda ise $\% 2.5$ olarak tespit etmiştir. Yön (2009), çok katlı perdeli-çerçeveli sistemler için zemin sınıfına bağlı olarak planda bulunması gereken perde duvar oranları belirlemiş olup, \%1.5 perde duvar oranına sahip 7 ve 9 katlı yapıların tüm zemin sınıflarında gerekli rijtliği sağladığını tespit etmiştir. Günel (2013), perde duvar oranının betonarme okul binalarının deprem yükleri altındaki davranışlarına etkisini incelemiştir. Yapılan doğrusal elastik olmayan değerlendirmeler sonucu perde duvar oranı \%1.5'a kadar çıkartıldığında çatı katı ötelenmeleri ve plastik şekil değiştirmelerin en küçük değerlerde olduğu, perde duvar oranı $\% 1.50$ değerini geçmesi durumunda ise, eklenen perde duvarların, binaların deprem performansına olan katkısının artmadığını tespit etmiştir.
DBYBHY (2007)'de binanın kullanım amacı ve türüne bağlı olarak farklı hedef performans seviyeleri verildiğinden, kat adetinden ve bina türünden bağımız olarak belirlenen perde duvar oranları yeterli düzeyde gerçekçi olmayacaktır.

Bu çalışmada, okul türü binaların DBYBHY (2007)'e göre yeterli düzeyde depreme karşı güvenli olabilmesi için planda bulunması gereken perde duvar oranı kat adetine bağlı olarak belirlenmiştir. Bunun için öncelikle perdeli çerçeveli model binalar seçilmiş, bu model binaların her biri doğrusal elastik olmayan yöntem ile performans değerlendirilmesine tabi tutulmuştur. Model binaların her biri DBYBHY (2007)'de öngörülen hedef performans seviyesini sağlayana kadar perde duvar boyutları artırılmış, böylece her bir model binadaki en küçük perde duvar boyutları elde etmiştir. Belirlenen en küçük perde duvar alanları kat alanlarına oranlanarak kat adetine bağlı perde duvar oranları belirlenmiştir.

\section{MATERYAL VE YÖNTEM}

\section{Binaların Deprem Güvenliği}

DBYBHY (2007)'de mevcut binaların performans seviyelerinin belirlenmesi için doğrusal elastik ve doğrusal elastik olmayan yöntem olmak üzere iki yöntem önerilmektedir. Önerilen iki yöntem de kendi içerisinde alt yöntemlere ayrılmaktadır. Önerilen bu iki yöntemden doğrusal elastik değerlendirme yönteminde, dayanım esaslı yaklaşım ile çözümleme yapılırken, doğrusal elastik olmayan değerlendirme yönteminde, şekil değiştirme ve yer değiştirme esaslı yaklaşım ile çözümleme yapılmaktadır.

Doğrusal elastik olmayan değerlendirme yöntemi ile binanın performans seviyesini belirleyebilmek için, ilk olarak binanın tepe yerdeğiştirme istemi belirlenir. Binanın hesaplanan bu tepe yerdeğiştirme istemi seviyesine kadar yatay yüke maruz kalması sonucu betonarme kesitlerde meydana gelen iç kuvvetlerin ve/veya şekil değiştirmelerin Tablo 1'de tanımlanan birim şekil değiştirme sınırları ile karşılaştırılması sonucunda, kesitlerin hangi hasar bölgelerinde olduğuna karar verilir. Elemanın en fazla hasar gören kesiti eleman hasarı olarak tanımlanır.

Tablo 1. Çeşitli kesit hasar sınırlarına göre izin verilen şekil değiştirme üst sınırları (DBYBHY,2007)

\begin{tabular}{|l|l|l|}
\hline Kesit hasar sınırı & Beton şekil değiştirme üst sınırları & Donatı çeliği şekil değiştirme üst sınırları \\
\hline Minimum Hasar Sınırı & $\left(\varepsilon_{\mathrm{cu}}\right)=0,0035$ & $\left(\varepsilon_{\mathrm{s}}\right)=0,010$ \\
\hline Güvenlik Sınırı & $\left(\varepsilon_{\mathrm{cg}}\right)=0,0035+0,01\left(\rho_{\mathrm{s}} / \rho_{\mathrm{sm}}\right) \leq 0,0135$ & $\left(\varepsilon_{\mathrm{s}}\right)=0,040$ \\
\hline Göçme Sınırı & $\left(\varepsilon_{\mathrm{cg}}\right)=0,004+0,014\left(\rho_{\mathrm{s}} / \rho_{\mathrm{sm}}\right) \leq 0.018$ & $\left(\varepsilon_{\mathrm{s}}\right)=0,060$ \\
\hline
\end{tabular}


Burada, $\varepsilon_{c u}$, kesitin en dış lifindeki beton basınç birim şekil değiştirmesini; $\varepsilon_{\mathrm{cg}}$, etriye içindeki bölgenin en dış lifindeki beton basınç birim şekil değiştirmesini; $\varepsilon_{\mathrm{s}}$, donatı çeliği birim şekil değiştirmesini; $\rho_{s}$, kesitteki enine donatının hacimsel oranını; $\rho_{s m}$, kesitte bulunması gereken enine donatının hacimsel oranını ifade etmektedir.

Hasar bölgesine karar verilen taşıyıcı elemanların kat içerisindeki oransal dağılımı değerlendirilerek kat performans seviyesi belirlenir. Bina deprem performans düzeyi ise en kritik katın performans seviyesine göre belirlenir (Şekil 1).

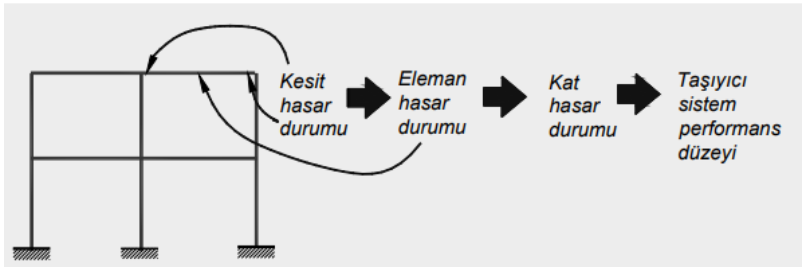

Şekil 1. Bina performans seviyesinin oluşumu (Celep, 2014)

DBYBHY (2007)'de; Hemen Kullanım (HK), Can Güvenliği (CG), Göçme Öncesi (GÖ) ve Göçme Durumu (GD) olmak üzere dört farklı performans düzeyi belirtilmiştir. Performans seviyesi tespit edilen binanın yeterli performans seviyesinde olup olmadığına, Tablo 2'de farklı deprem düzeylerine göre verilen minimum performans hedeflerine göre karar verilir.

Tablo 2. Farklı deprem düzeylerinde binalar için öngörülen minimum performans hedefleri (DBYBHY, 2007)

\begin{tabular}{|l|c|c|c|}
\hline \multicolumn{1}{|c|}{ Binanın Kullanım Amacı ve Türü } & \multicolumn{2}{c|}{ Depremin Aşılma Olasılığı } \\
\cline { 2 - 4 } & 50 yılda \%50 & 50 yıılda \%10 & 50 yılda \%2 \\
\hline $\begin{array}{l}\text { Deprem Sonrası Kullanımı Gereken Binalar: Hastaneler, sağlık te- } \\
\text { sisleri, itfaiye binaları, haberleşme ve enerji tesisleri, ulaşım istas- } \\
\text { yonları, vilayet, kaymakamlık ve belediye yönetim binaları, afet yö- } \\
\text { netim merkezleri, vb. }\end{array}$ & - & HK & CG \\
\hline $\begin{array}{l}\text { Insanların Uzun Süreli ve Yoğun Olarak Bulunduğu Binalar: Okullar, } \\
\text { yatakhaneler, yurtlar, pansiyonlar, askeri kışlalar, cezaevleri, müze- } \\
\text { ler, vb. }\end{array}$ & - & HK & CG \\
\hline $\begin{array}{l}\text { Insanların Kısa Süreli ve Yoğun Olarak Bulunduğu Binalar: Sinema, } \\
\text { tiyatro, konser salonları, kültür merkezleri, spor tesisleri }\end{array}$ & HK & CG & - \\
\hline $\begin{array}{l}\text { Tehlikeli Madde İçeren Binalar: Toksik, parlayıcı ve patlayıcı özellik- } \\
\text { leri olan maddelerin bulunduğu ve depolandığı binalar }\end{array}$ & - & HK & GÖ \\
\hline $\begin{array}{l}\text { Diğer Binalar: Yukarıdaki tanımlara girmeyen diğer binalar (konutlar, } \\
\text { işyerleri, oteller, turistik tesisler, endüstri yapıları, vb.) }\end{array}$ & - & CG & - \\
\hline
\end{tabular}

\section{Model Binalar}

Çoğu zaman bina planlarında düzensizlikler bulunmaktadır. Bu düzensizliklerin özellikle yönetmelikte verilen sınır değerlerin aşılması durumunda binanın deprem yükleri altındaki davranışını olumsuz yönde etkilediği bilinmektedir. Düzensizliklerin binanın deprem performansını da etkileyeceği söylenebilir. Bu nedenle DBYBHY (2007)'de performans belirleme yöntemlerinin uygulanabilmesi için sınır değerler getirilmiştir. Bu çalışmada yapılan çözümlemelerde düzensizliklerin olumsuz etkileri dikkate alınmamış, incelenecek parametre sayısını azaltmak için düzenli binalar tercih edilmiştir.

\section{Model Binaların Tanıtılması ve Modellenmesi}

Çalışma kapsamında üç tip model bina kalıp planı seçilmiş, bu kalıp planları KP1, KP2 ve KP3 olarak adlandırılmıştır. KP1 olarak adlandırılan model bina $300 \mathrm{~m}^{2}$ taban alanına sahip olup her bir katta 4 adet dersliği bulunmakta, KP2 olarak adlandırılan model bina $430 \mathrm{~m}^{2}$ taban alanına sahip olup her bir katta 6 adet dersliği bulunmakta, KP3 olarak adlandırılan model bina $550 \mathrm{~m}^{2}$ taban alanına sahip olup her bir katta 8 adet dersliği bulunmaktadır. Model binaların özellikleri Tablo 3'te verilmiştir. 
Tablo 3. Model binaların özellikleri ve adlandırılması

\begin{tabular}{|c|c|c|c|}
\hline Model bina adı & Her bir kattaki derslik sayısı & Kat taban alanı $\left(\mathrm{m}^{2}\right)$ & Geometrik şekli \\
\hline KP1 & 4 & 300 & Kare/Simetrik \\
\hline KP2 & 6 & 430 & Dikdörtgen/ Simetrik değil \\
\hline KP3 & 8 & 550 & Dikdörtgen/ Simetrik \\
\hline
\end{tabular}

Seçilen tip model binaların kalıp planları Şekil 2'de verilmiştir. Model binalarda perde duvar yerleşimi tip okul binalarını yansıtması için sınıf kullanım ve düzenini engellemeyecek şekilde yerleştirilmiştir.

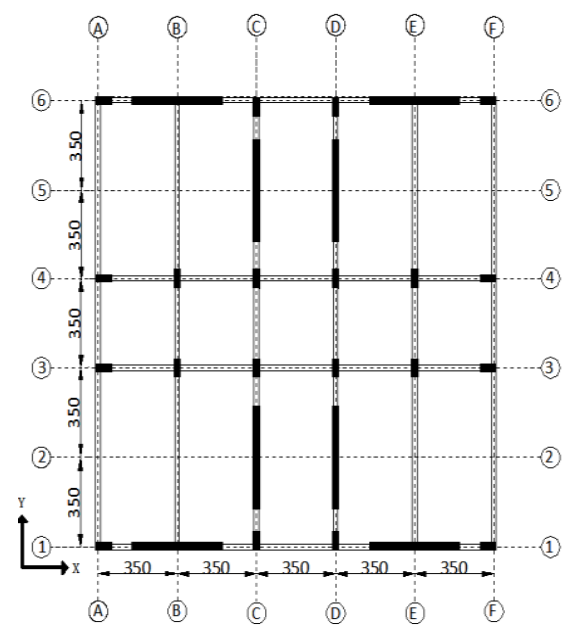

(a)

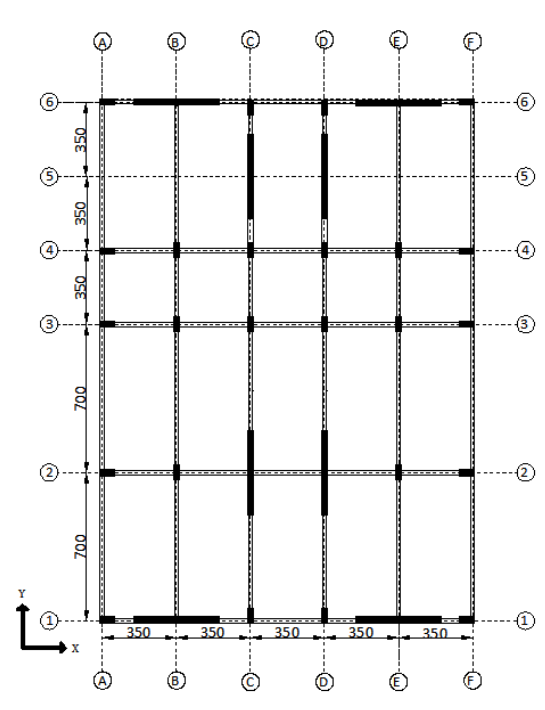

(b)

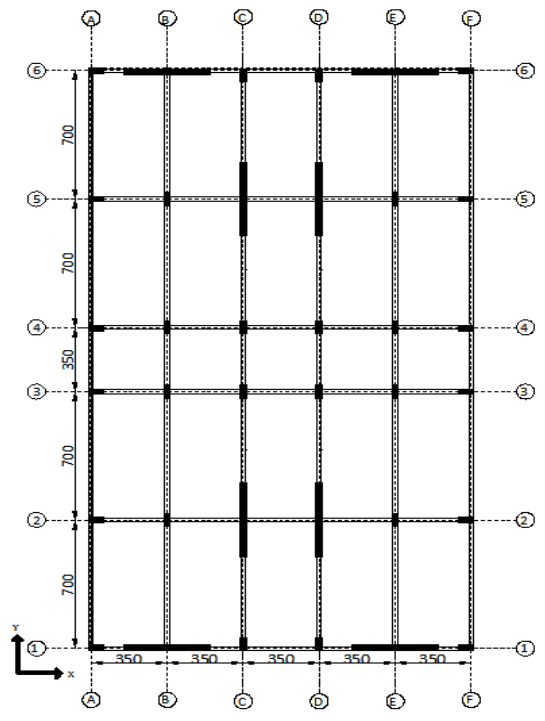

(c)

Şekil 2. KP1(a), KP2(b) ve KP3(c) isimli model binaların kalıp planları (ölçüler cm.)

Oluşturulan model binaların kat adetleri 2, 3, 4 ve 5; kat yükseklikleri ise 3,5 m olarak belirlenmiştir. Model binaların her biri 2 tip malzeme grubu için çözülmüştür. Birinci tip malzeme grubu, yurdumuzdaki binaların genel malzeme durumlarını yansıtması için C10-S220-"Sargı Yok" olarak seçilmiştir. İkinci tip malzeme grubu ise binalarının projede öngörülen malzeme durumlarını yansıtması için C20-S420-"Sargı Var" olarak seçilmiştir. Burada C10 ve C20 beton sınıfını, S220 ve S420 donatı sınıfını, Sargılamanın "Var" olması mesnet bölgelerinde $100 \mathrm{~mm}$ aralıklarla etriye bulunduğunu, "Yok" olması ise mesnet bölgelerinde $200 \mathrm{~mm}$ aralıklarla etriye bulundu-

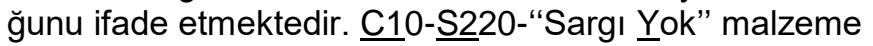
grubu kısaca C1S2Y olarak, C20-S420-“Sargı Var" malzeme grubu ise kısaca C2S4V olarak adlandırımıştır. Model binalar; kat alanı, kat adedi ve malzeme durumuna bağlı olarak Şekil 3'te görüldüğü gibi sınıflandırılmıştır.

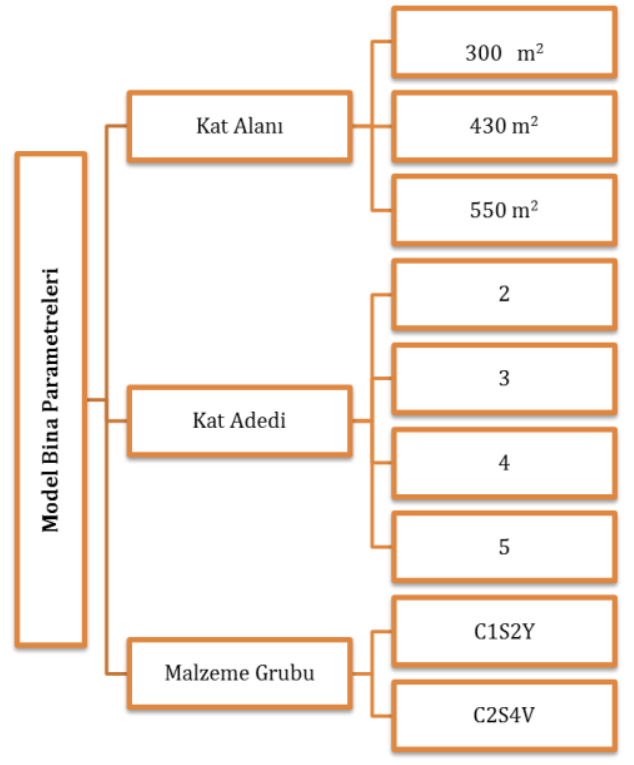

Şekil 3. Model bina parametreleri 
Çalışma kapsamında seçilen tüm model binaların 1. derece deprem bölgesinde ve Z4 sınıfı yerel zemin bölgesinde bulunduğu kabul edilerek etkin yer ivmesi katsayısı $A_{0}=0.40$ ve spektrum karakteristik periyotları $T_{A}=0.2 s, T_{B}=0.9 \mathrm{~s}$ olarak belirlenmiştir. Döşeme sabit yük değeri (g) $4 \mathrm{kN} / \mathrm{m}^{2}$, hareketli yük değeri (q) ise TS 498 (1987)'in okullar için öngörüldüğü şekilde sınıflarda $3,5 \mathrm{kN} / \mathrm{m}^{2}$, koridorlar da $5 \mathrm{kN} / \mathrm{m}^{2}$ olarak dikkate alınmıştır. Duvar sabit yükleri ( $\mathrm{g}_{\text {duvar}}$ ) ise tüm kirişlerin üstüne $4 \mathrm{kN} / \mathrm{m}$ olarak aktarılmıştır. Hesaplamalarda hareketli yük azaltma katsayısı 0,6 alınmıştır.

Oluşturulan model binaların kolon boyutları kat içerisinde ve tüm katlar boyunca aynı olacak şekilde seçilmiştir. Kolon boyutları kat adedine ve malzeme grubuna bağlı olarak değişmekte olup, kolon kesitlerine ait görünümler Şekil 4 ve Şekil 5 'te verilmiştir. Şekil 4 ve Şekil 5 'te verilen kolon boyut ölçüleri cm'dir. Kolon kesitlerinin donatı oranı; DBYBHY (2007)'deki minimum donatı oranı olan \%1 seçilmiştir. Perde duvar kesitleri ise, tüm modellerde ilk olarak $30 \times 210 \mathrm{~cm}$ seçilmiş ve binanın performans seviyesi belirlenmiştir. Hedef performans seviyesinin sağlanmaması durumunda perde duvar boyutları hesap yapılan doğrultuda $5 \mathrm{~cm}$ arttırılmış ve binanın performans seviyesi yeniden belirlenmiştir. $\mathrm{Bu}$ işleme her iki doğrultuda da hedef performans sağlanana kadar devam edilmiştir. Dolayısıyla model binalarında hedef performans seviyesinin sağlanması için gerekli olan minimum perde duvar miktarı belirlenmiştir. Perde duvarlara DBYBHY (2007)'de verilen minimum donatı oranı kullanılarak donatı yerleştirilmiştir. Bunun için perde duvarların uç kısımların her birine $\% 0,2$, gövde kısmına ise $\% 0,25$ oranında donatı yerleştirilmiştir. Kiriş elemanların kesit boyutları ise tüm modellerde aynı olacak şekilde $25 \times 50 \mathrm{~cm}$ olarak hesaplara katılmıştır.

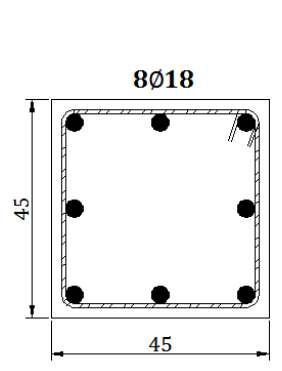

(a) 2 katlı

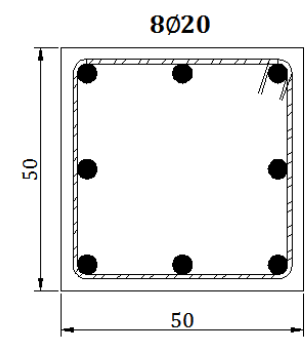

(b) 3 katlı

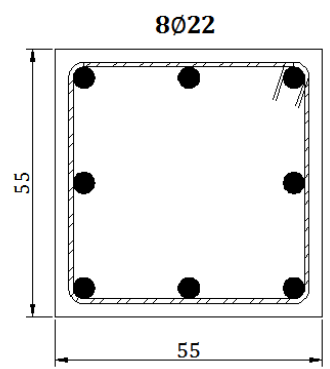

(c) 4 katlı

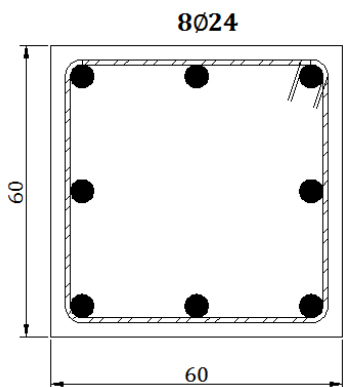

(d) 5 katlı

Şekil 4. C1S2Y malzeme grubu kolon kesitleri

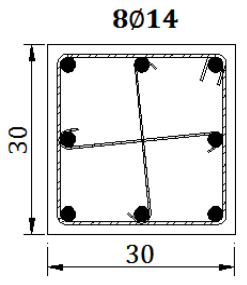

(a) 2 katlı

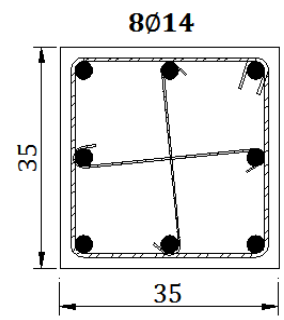

(b) 3 katlı

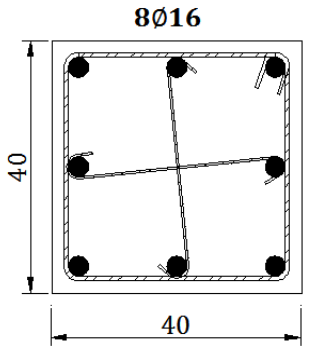

(c) 4 katlı

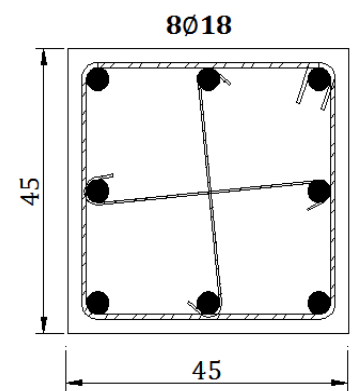

(d) 5 katlı

Şekil 5. C2S4V malzeme grubu kolon kesitleri

Modellemede yapılan bazı kabuller aşağıda sıralanmıştır.

Kolon, kiriş ve perde duvarlar çubuk eleman olarak modellenmiştir.

$>$ Kirişlerin kolon ve perde duvar ile kesiştiği bölgeler sonsuz rijit olarak modellenmiştir.

> Alt kat kolonları temele ankastre olarak mesnetlenmiştir.
> Tüm döşemelerin kendi kat seviyelerinde rijit diyafram olarak çalıştığı kabul edilmiştir.

> Döşeme sabit ve hareketli yükleri kirişlere üçgen ve trapez, duvar yükleri ise kirişlere düzgün yayılı yük olarak aktarılmıştır.

Seçilen model binalara ait kalıp planları belirtilen parametreler dikkate alınarak SAP 2000 programında modellenmiştir. 2 katlı model binalar için oluşturulan SAP 2000 modelleri Şekil 6'da verilmiştir. 


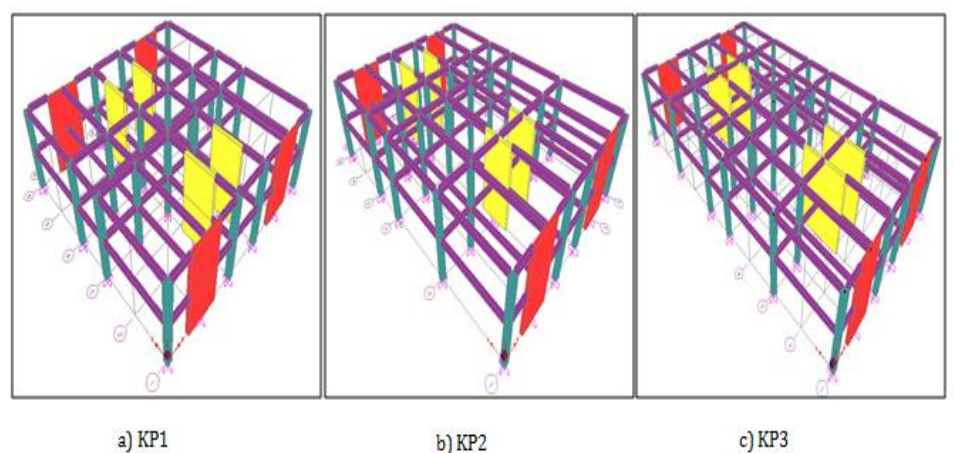

Şekil 6. İki katlı model binalar için oluşturulan SAP 2000 modelleri

Model binaların performans değerlendirmesinde yapılan kabuller aşağıdaki sıralanmıştır.

> Kirişlerde oluşan hasarların, binanın toptan göçmesine sebep olmaması, kirişin çalışan kesitinin tanımının yönetmeliklerde farklı verilmesi, yönetmelikte, döşeme donatısının bir kısmının, kiriş donatısı olarak göz önüne alınabilmesinin öngörülmesi, kiriş eğilme rijtilikleri değiştirilerek, kiriş etkisinin azaltılmasının (kolon etkisini çoğaltacaktır) mümkün olması, kiriş hasarlarının, kolon hasarlarına göre daha az önemli olması gibi nedenlerle kısa kirişlerde oluşan hasarlarının göz ardı edilebileceği kabul edilmiştir.

$>$ Analizlerde kiriş, kolon ve perde duvarların çatlamış kesit eğilme rijitlikleri kullanılmıştır. Çatlamış kesit eğilme rijitlikleri DBYBHY (2007)'e göre tanımlanmıştır.

> Her bir kesit için moment-eğrilik ilişkisinden yararlanarak moment-dönme ilişkileri oluşturulmuştur. Kesitlerin moment-eğrilik ilişkilerinden moment-dönme ilişkisine geçişlerde DBYBHY (2007)'de önerilen yığılı plastik davranış modeli kullanılmıştır.

> Plastik mafsal boyu olarak adlandırılan plastik şekildeğiştirme bölgesinin uzunluğu $\left(L_{p}\right)$, depremde etkili olan boyutun $(\mathrm{h})$ yarısına eşit alınmıştır ( $\left.\mathrm{L}_{p}=0,5^{*} \mathrm{~h}\right)$.

$>$ Kesit hasar sınırlarına göre izin verilen şekildeğiştirme üst sınırları kullanılarak bu sınır değerlere tekabül eden moment-dönme değerleri BESAM (2013) programı yardımı ile belirlenmiş ve eleman hasar sınırları plastik mafsal üzerinde tanımlanmıştır.

> Plastik şekil değiştirmelerin, kolon ve kiriş elemanlarının her iki uç bölgesine, perde elemanların ise alt uç bölgesine tanımlanan plastik mafsallarda oluştuğu varsayılmıştır. Kirişlerde plastikleşmenin tek eksenli eğilme momenti ile (M3), kolon ve perde duvarlarda ise iki eksenli eğilme momenti ve eksenel kuvvetin etkileşimi ile (P-M2-M3) oluştuğu kabul edilmiştir.

$>$ Model binalar performans değerlendirmeleri, doğrusal elastik olmayan değerlendirme yöntemlerinden artımsal eşdeğer deprem yükü hesap yöntemi kullanılarak yapılmıştır.
> Doğrusal olmayan statik itme analizinde binalara uygulanan yük dağılımı, analizin başlangıç adımında doğrusal elastik davranış için hesaplanan birinci (deprem doğrultusundaki hakim) doğal titreşim mod şekli genliği ile ilgili kütlenin çarpımından elde edilen değerle orantılı olacak şekilde tanımlanmıştır.

> Yapı sistemi önce kütlelerle uyumlu düşey yükler altında doğrusal olmayan statik analiz ile çözülmüştür. Elde edilen bu analizin sonuçları artımsal itme analizinin başlangıç koşulları olarak hesaba katılmıştır.

\section{Model Binalar için Elde Edilen Sonuçlar}

Çalışma kapsamında okul türü binalar incelendiği için model binaların hedeflenen performans seviyeleri DBYBHY (2007)'de belirtilen 50 yılda aşılma olasılığı $\% 10$ olan depremler için Hemen Kullanım, 50 yılda aşılma olasılığı \%2 olan depremler için Can Güvenliği olacak şekilde tanımlanmıştır.

Seçilen 24 adet model binanın her biri aşııma olasılığına göre hedeflenen minimum hedef performans seviyelerini sağlayana kadar perde duvarlar hesap yapılan doğrultuda 5'er cm artırılarak öngörülen performans seviyesini sağlayan en küçük perde duvar boyutları elde edilmiştir. Aynı işlemler her iki doğrultu için de yapılmıştır. Aranan perde duvarların boyutları modeller için yaklaşık 8-15 denemede elde edilmiştir. Dolayısıyla, çalışma kapsamında model binalar için yaklaşık 750 adet doğrusal elastik olmayan çözüm yapıldığı söylenebilir.

Elde edilen çözümler kalıp planı, kat adedi ve değerlendirme yapılan yöne bağlı olarak adlandırılmıştır. Örneğin "K12X"; KP1 kalıp planına sahip model binanın 2 katlı modelinin $\underline{X}$ yönü çözümüne ait sonucu ifade etmektedir. $\mathrm{C} 1 \mathrm{~S} 2 \mathrm{Y}$ ve $\mathrm{C} 2 \mathrm{~S} 4 \mathrm{~V}$ malzeme gruplarının her biri için kat seviyesine bağlı olarak elde edilen kat perde alanlarının $\left(A_{p}\right)$ kat alanlarına $\left(A_{k}\right)$ oranları $\left(A_{p} / A_{k}\right)$ Şekil 7 ve Şekil 8'de verilmiştir. 


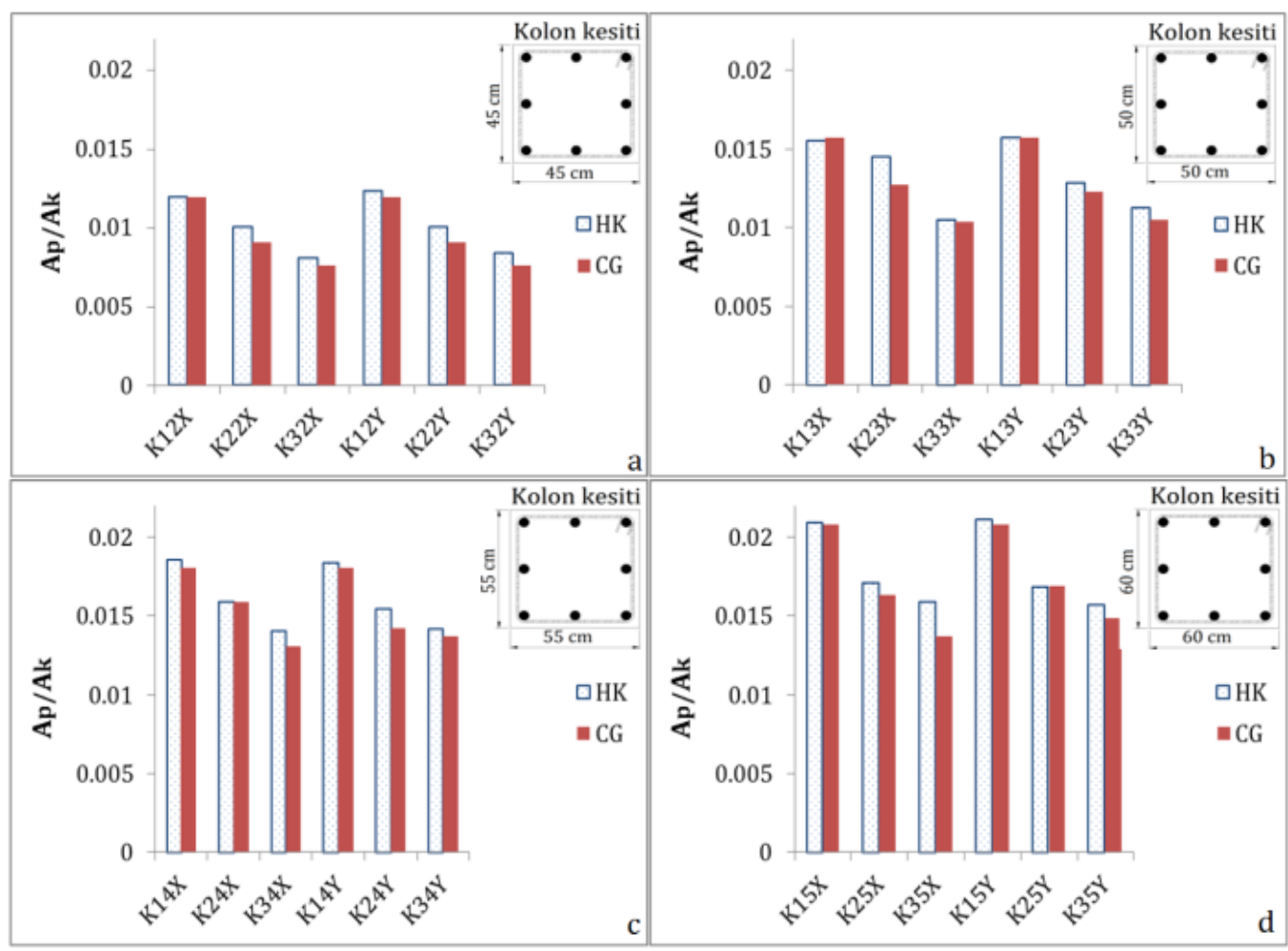

Şekil 7. C1S2Y malzeme grubu için 2 katı(a), 3 katı(b), 4 katı(c), 5 katı(d) model binalardan elde edilen en küçük $A_{p} / A_{k}$ değerleri

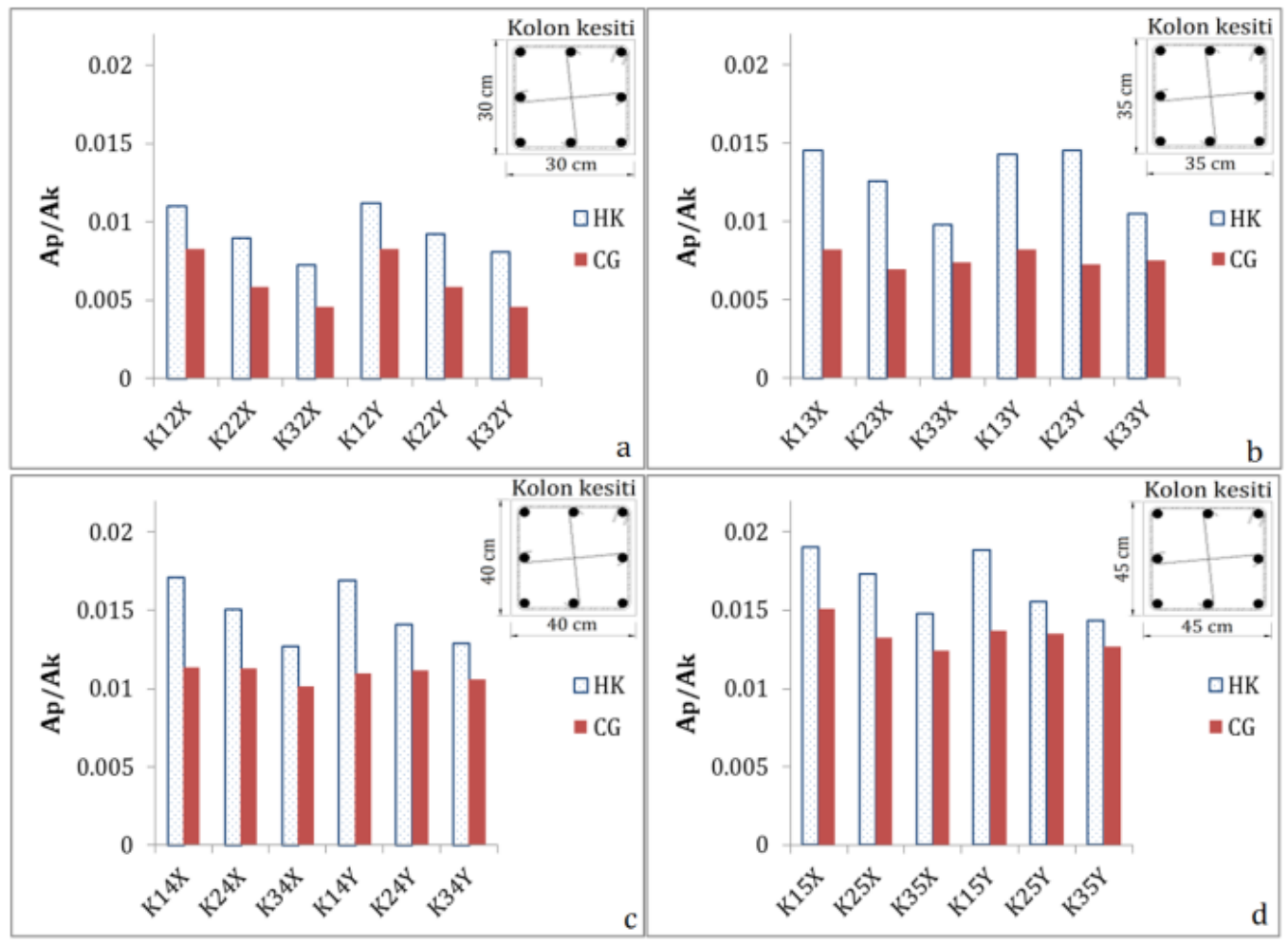

Şekil 8. C2S4V malzeme grubu için 2 katı(a), 3 katı(b), 4 katı(c), 5 katı(d) model binalardan elde edilen en küçük $A_{p} / A_{k}$ değerleri 
Yapılan çözümlerde 50 yılda aşılma olasılığı \%10 olan depremler için ve 50 yılda aşılma olasılığı \%2 olan depremler için elde edilen perde boyutlarından en elverişsiz olanı (en büyük perde boyuna sahip olan) bina deprem performansının sağlanması için gereken minimum perde duvar boyutu olarak tanımlanmıştır. Okul binaları için önerilecek olan perde duvar oranı için en elverişsiz olan bu perde boyutları etkin parametre olarak kullanılmıştır. Kat seviyesine bağlı olarak en elverişsiz perde boyutları ile elde edilen perde alanının kat alanına oranları $\left(A_{p} / A_{k}\right)$ Şekil 9 ve Şekil 10'da verilmiştir.

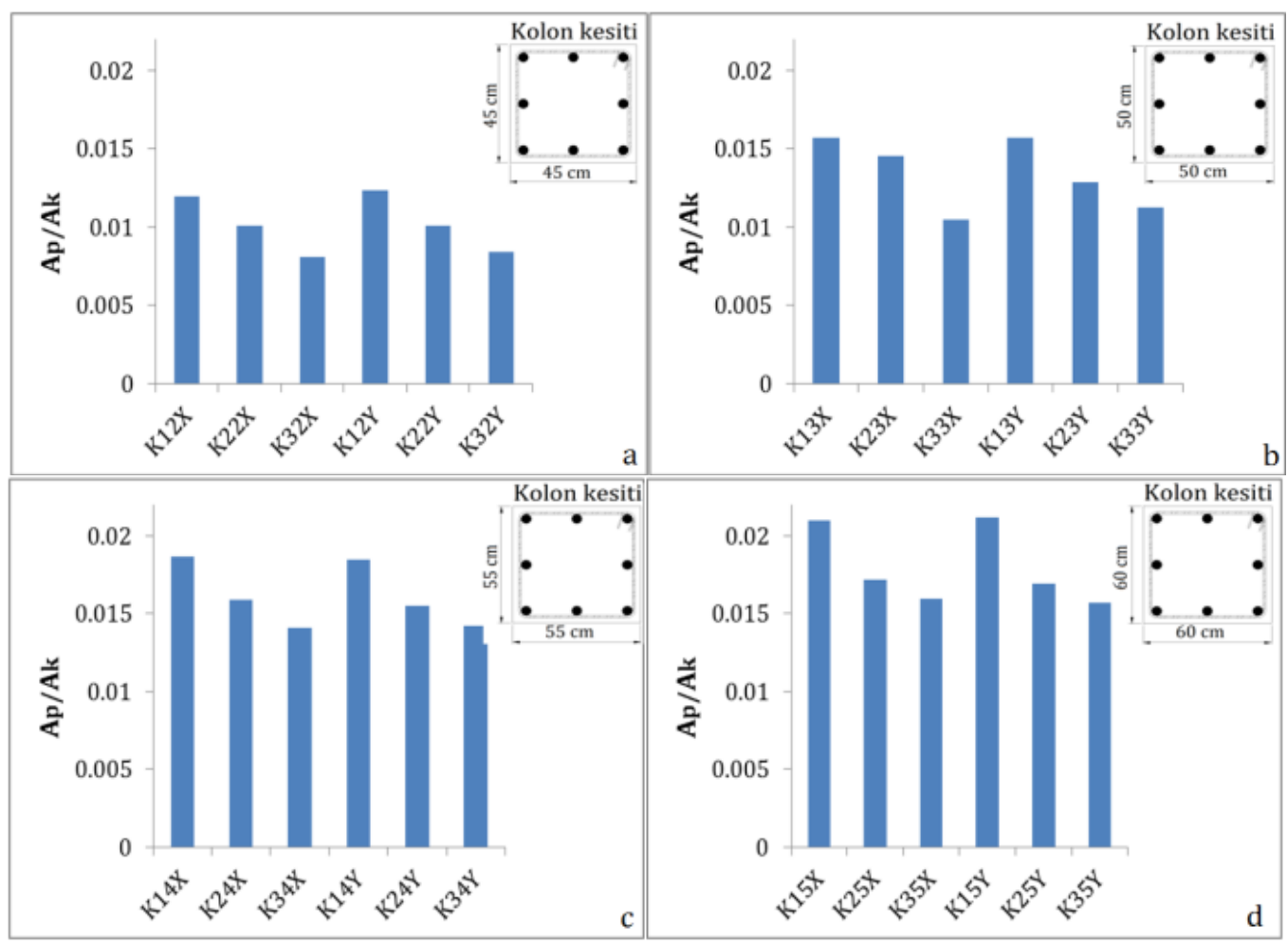

Şekil 9. C1S2Y malzeme grubu için 2 katı(a), 3 katı(b), 4 katıı(c), 5 katı(d) model binalarda elde edilen en elverişsiz $A_{p} / A_{k}$ değerleri 


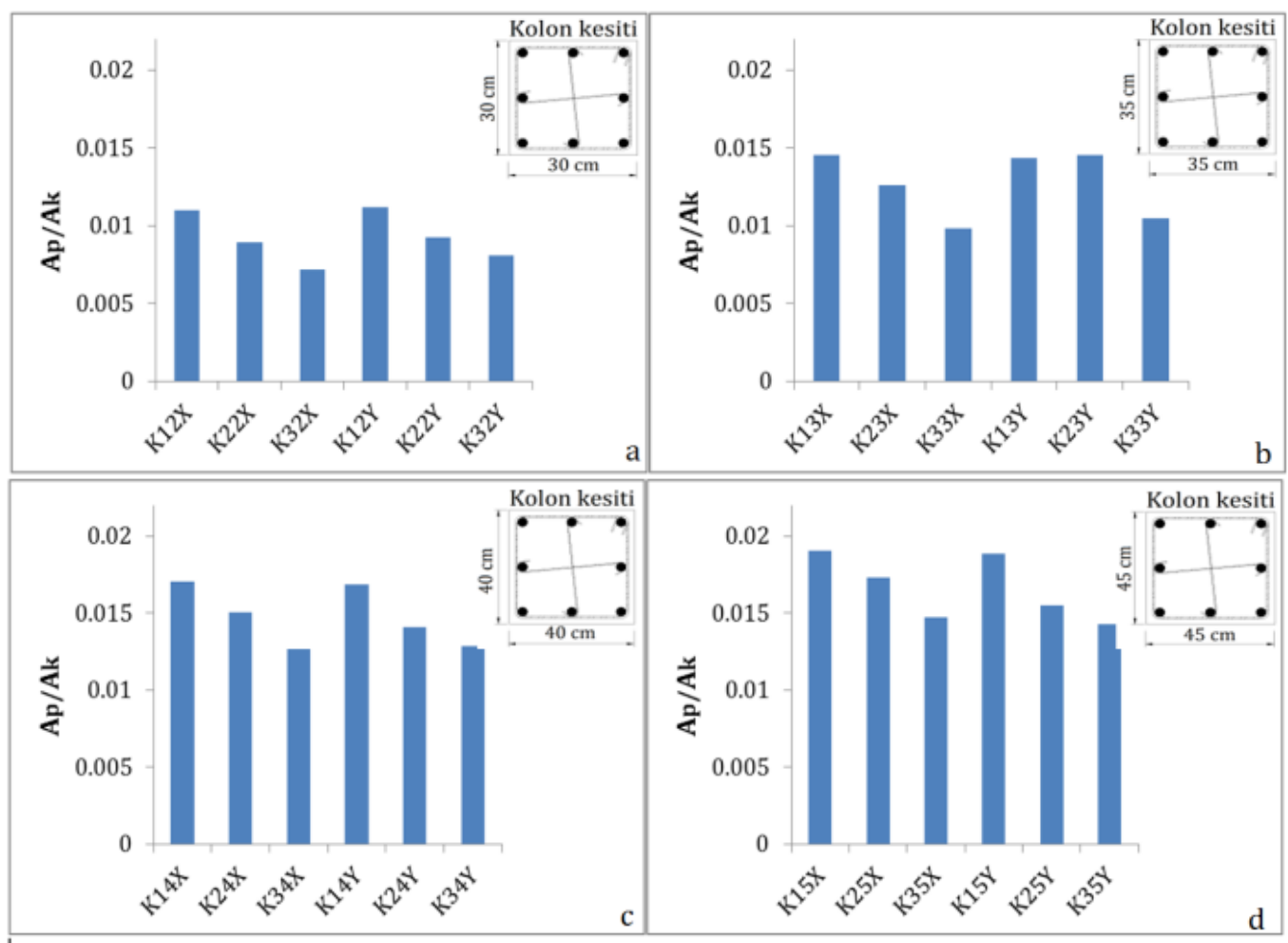

Şekil 10. C2S4V malzeme grubu için 2 katı(a), 3 katı(b), 4 katı(c), 5 katı(d) model binalarda elde edilen en elverişsiz $A_{p} / A_{k}$ değerleri

C1S2Y malzeme grubu ile çözülen model binalardan, minimum hedef performans seviyesini sağlayan en küçük betonarme perde boyutlarından en elverişsiz olanların kullanılması ile $A_{p} / A_{k a t}$ (kat perde duvar alanı/kat alanı) oranı; 2 katlı binalarda \%1,12; 3 katlı binalarda $\% 1,57 ; 4$ katlı binalarda \%1,86; 5 katlı binalarda \%2,1 olarak elde edilmiştir.

C2S4V malzeme grubu ile çözülen model binalardan, minimum hedef performans seviyesini sağlayan en küçük betonarme perde boyutlarından en elverişsiz olanların kullanılması ile $A_{p} / A_{k a t}$ (kat perde duvar alanı/kat alanı) oranı 2 katı binalarda \%1,11; 3 katı binalarda $\% 1,45 ; 4$ katlı binalarda \%1,71; 5 katlı binalarda \%1,9 olarak elde edilmiştir

\section{SONUÇ VE ÖNERILER}

Bu çalışma kapsamında, okul türü binaların DBYBHY (2007)'e göre yeterli düzeyde depreme karşı güvenli olması için binada bulunması gereken betonarme perde miktarı kat adetine bağlı olarak oransal olarak belirlenmiştir. Bu amaçla 24 adet model bina seçilmiştir. SAP 2000 programında oluşturulan model binaların her biri aşılma olasılığına göre hedeflenen minimum hedef performans seviyelerini sağlayana kadar betonarme perdeler her iki yönde 5'er cm artırılarak öngörülen performans seviyesini sağlayan en küçük perde duvar boyutları her iki doğrultu için elde edilmiştir. Belirlenen bu perde duvar boyutları kat alanlarına bölünerek kat adetine bağlı olarak perde duvar oranları belirlenmiştir. Yapılan çözümler ışığında aşağıdaki değerlendirmeler yapılmıştır.

> Yapılan çözümleler sonucu her iki malzeme grubundan elde edilen en elverişsiz perde duvar oranlarının ortalaması alınması ile malzemeden bağımsız olarak okul binalarında bulunması gereken perde duvar oranları elde edilmiştir. Bu durumda doğrusal elastik olmayan değerlendirme ile okul binalarının depreme karşı güvenli olabilmesi için; 2 katlı binalarda $\% 1,12$; 3 katlı binalarda \%1,51; 4 katı binalarda \%1,79; 5 katlı binalarda \%2 oranında perde duvar gerekeceği söylenebilir

$>$ C1S2Y malzeme grubu ile yapılan performans değerlendirmelerinde 50 yılda aşılma olasılığı \%10 olan depremler ile 50 yılda aşılma olasılığı \%2 olan depremlerin hangisinin daha kritik sonuçlar vereceği net olarak söylenemezken, C2S4V malzeme grubu ile yapılan performans değerlendirmelerinde 50 yılda aşııma olasılığı \%10 olan depremler ile elde edilen sonuçların daha kritik sonuçlar verdiği söylenebilir.

> DBYBHY (2007)'de deprem sonrası kullanımı gereken binalar (hastaneler, sağlık tesisler, vb.) ile insanların uzun süreli ve yoğun olarak bulunduğu binaların (okullar, yatakhaneler, yurtlar, vb.) farklı aşılma olasılıkları için öngörülen minimum hedef performans 
seviyeleri aynı verildiğinden okul türü binaları için belirlenen betonarme perde oranları bu yapılar içinde kullanılabilir.

Çalışma kapsamında belirlenen betonarme perde oranları düzenli kalıp planları kullanılarak elde edilmiş, bu oranlar bina düzensizliklerine, dolgu duvar etkisine, farklı zemin sınıfına, farklı sargı aralığına, farklı deprem bölgelerine, bina türüne göre ayrı ayrı bir şekilde geliştirilebilir.

\section{KAYNAKLAR}

Atımtay, E. (2001). Çerçeveli ve Perdeli Betonarme Sistemlerin Tasarımı: Temel Kavramlar ve Hesap Yöntemleri. Bizim Büro, Ankara

BESAM (2013). Betonarme Elemanlarda Sargı ve Modelleme Programı. TÜBITAK 111M119.

Celep, Z. (2014). Betonarme Taşıyıcı Sistemlerde Doğrusal Olmayan Davranış ve Çözümleme. Beta Dağıtım, İstanbul.

DBYBHY (2007). Deprem Bölgelerinde Yapılacak Binalar Hakkında Yönetmelik. Bayındırlık ve İskân Bakanlığı, Ankara.
Erken, S. (2012). Betonarme Yapıların Taşıyıcı Sistem Seçiminde Perde Yerleşiminin Davranışa Etkisi. Yüksek Lisans Tezi, İstanbul Teknik Üniversitesi, Fen Bilimleri Enstitüsü.

Engin, S. (2017). Binalar için gerekli perde duvar oranının farklı depremler için incelenmesi. 4. Uluslararası Deprem Mühendisliği ve Sismoloji Konferansı. 11-13 Ekim 2017, Eskişehir.

Günel, A.O. (2013). Influence of the Shear Wall Area to Floor Area Ratio on the Seismic Performance of Existing Reinforced Concrete Buildings. Middle East Technical University Natural and Applied Sciences, M. Sc. Thesis, 153s, Ankara.

SAP 2000 (2011). Computers and Structures, Inc., v.14.2.0, Structural Analysis Program, Berkeley, CA, USA.

Şahin, H., Alyamaç, K.E., Erdoğan, S. (2013). Perdeli Çerçeveli Yapılarda Zemin Sınıfı ve Kat Adedi Dikkate Alınarak Gerekli Perde Oranının Tespiti. SDU International Technologic Science, 5(1): 74- 86

TS498 (1987). Yapı Elemanlarının Boyutlandırmasında Alınacak Yüklerin Hesap Değerleri. Türk Standartları Enstitüsü.

Yön, B., Şahin, H. (2009). Çok Katı Betonarme Binalarda Zemin Sınıfına Göre Deprem Perdesi Oranının Tespiti. Uludağ Üniversitesi Mühendislik- Mimarlık Fakültesi Dergisi, 14(2): 57-73. 